\title{
Hvis jorden var vår pasient
}

\author{
Resultatene fra klimakonferansen i Durban 2011 bekrefter at politikerne ikke evner å gjøre det klima- \\ situasjonen krever. Før fem år er gått må en radikalt ny klimapolitikk være på plass. Som leger har vi et \\ spesielt ansvar for å bidra til klimarevolusjonen som er nødvendig for å forebygge helseskader som følge \\ av klimaendringene.
}

I løpet av de siste årene er de dramatiske helsekonsekvensene som kan forventes på grunn av klimaendringene klart beskrevet (1). Problemet kan ikke møtes på samme måte som andre viktige årsaker til dårlig global helse, som fattigdom og sosiale ulikheter. For å bekjempe disse problemene har man bl.a. satset på reduksjon av fattigdom ved å fremme en økonomisk vekst basert på økende bruk av fossilt brennstoff. Fortsatt karbonbasert materiell vekst er imidlertid ikke mulig, på grunn av klimaendringene og jordens begrensende ressurser. Professor Hugh Montgomery fra det engelske Climate and Health Council beskriver situasjonen slik: "Were the world a patient, we'd be calling the cardiac arrest team just now» (2).

\section{Farlige klimaendringer}

Det internasjonale energibyrået IEA la nylig frem en foruroligende rapport (3). Den viser at fire femdeler av de totale utslippene som kan tillates før 2035 for å kunne nå togradersmålet for global oppvarming allerede er disponert av eksisterende energiproduserende enheter, bygninger og fabrikker. Om ikke radikale tiltak settes i verk innen 2017, vil den energirelaterte infrastrukturen som da er kommet på plass, være så stor at den siste femdelen av utslippene er bundet opp. Dette vil bety at det etter 2017 ikke vil være rom for ny infrastruktur som medfører klimagassutslipp. Den verdensledende klimaforskeren James Hansen kaller selv togradersmålet «en oppskrift på katastrofe», og FNs klimasjef Chistiana Figueres går inn for at grensen må settes til lavere enn 1,5 grader (4).

Beregninger fra Potsdam-instituttet for klimaforskning publisert i 2009 viser at under halvparten av de da kjente og økonomisk utnyttbare reserver av kull, olje og gass kan brukes om man skal ha en realistisk sjanse til å nå togradersmålet for global oppvarming (5). Derfor må produksjonen av kull, olje og gass trappes ned lenge før lagrene er tomme, og det er avgjørende viktig at ukonvensjonelle kilder som oljesand ikke tas i bruk.

\section{Ukontrollerbare utslipp fra tinende permafrost}

Det er beregnet at omkring 1700 milliarder tonn organisk karbon er bundet i frossen jord i nordområdene (6). Dette svarer til mer enn fire ganger så mye som alle karbonutslipp fra menneskelig aktivitet i moderne tid og dobbelt så mye som det som nå finnes $i$ atmosfæren. Hvis permafrosten tiner, kan store mengder klimagasser bli frigjort til atmosfæren - det meste $\mathrm{i}$ form av $\mathrm{CO}_{2}$, men noe i form av metan, som har en drivhuseffekt som er om lag 25 ganger sterkere enn for $\mathrm{CO}_{2}$. Dette kan utløse en ukontrollerbar tilbakekoblingsmekanisme - med raskere global oppvarming, som igjen gir forsterket tining av permafrosten og ytterligere økning av klimagassutslippene.

I en fersk artikkel i Nature uttrykkes stor bekymring for denne tilbakekoblingsmekanismen, siden disse utslippene skjer uten at vi har muligheter for å stoppe dem og fordi de vil vedvare lenge når de først er startet (6). For å kunne begrense en slik tilbakekoblingsmekanisme understreker forskerne at det haster svært med å begrense klimagassutslippene fra fossilt brennstoff fra menneskelig aktivitet som vi selv kan ha kontroll over. The Independent rapporterte nylig at russiske forskere er sjokkert over observasjoner av store utslipp av metan fra havbunnen utenfor Sibir (7).

\section{Vårt ansvar som leger}

Som leger har vi et viktig ansvar som varslere om helsekonsekvenser av politiske beslutninger. I dette tilfellet er konsekvensene meget alvorlige - og det finnes forebyggende tiltak som kan redusere dem. Vi har derfor et spesielt ansvar for å bidra til en klimapolitikk som fører til reduserte klimagassutslipp raskt nok til å kunne forebygge de alvorlige helseskadene som følger av klimaendringene.

Verdenssamfunnet og ansvarlige enkeltnasjoner må innse at forhandlinger av typen vi har sett i København, Cancun og Durban ikke vil føre frem. Vi kan ikke fortsette å bruke fossilt brennstoff for å opprettholde et unødvendig høyt forbruk i den rike del av verden og slik ødelegge våre barns fremtid for å tilfredsstille vår umettelige appetitt på luksus. Vår egen nobelprisvinner Trygve Haavelmo (1911-99) sa allerede for mange år siden: «Mer vekst $\mathrm{i}$ de rike landene er en forferdelig tanke» (8).

Legeforeningen har vært tydelig og understreket viktigheten av dette feltet (9). Engasjerte leger kan også involvere seg i Norsk nettverk for klima og helse og i det britiske Climate and Health Council.

\section{Gunnar Kvåle}

gunnar.kvale@cih.uib.no

Senter for internasjonal helse

Universitetet i Bergen

Gunnar Kvåle (f. 1942) er professor ved Senter for internasjonal helse og medlem i koordinatorgruppen for Norsk nettverk for klima og helse.

Forfatter har fylt ut ICMJE-skjemaet og oppgir ingen interessekonflikter.

\section{Litteratur}

1. Costello A, Abbas M, Allen A et al. Managing the health effects of climate change: Lancet and University College London Institute for Global Health Commission. Lancet 2009; 373: 1693-733.

2. Nell Crowden. Hugh's views on COP17. Climate and Health Council, 2011.

www.climateandhealth.org/magazine/read/ hughs-views-on-cop17_158.html (22.12.2011)

3. International Energy Agency. World Energy Outlook, 2011. Executive Summary. www.iea.org/weo/ (22.12.2011).

4. Fiona Harvey. UN chief challenges world to agree tougher target for climate change. The Guardian 1.6.2011. www.guardian.co.uk/environment/2011/ jun/01/climate-change-target-christiana-figueres (22.12.2011).

5. Meinshausen M, Meinshausen N, Hare W et al. Greenhouse-gas emission targets for limiting global warming to 2 degrees C. Nature 2009; 458 1158-62.

6. Schuur EAG, Abbott B. Climate change: High risk of permafrost thaw. Nature 2011; 480: 32-3.

7. Connor S. Vast methane 'plumes' seen in Arctic ocean as sea ice retreats. The Independent 13.12.2011. www.independent.co.uk/news/ science/vast-methane-plumes-seen-in-arcticocean-as-sea-ice-retreats-6276278.html (11.1.2012)

8. Vermes T. Men hva med norsk livsstil? Livsstilen i Norge står heller ikke på dagsordenen i norsk klimadebatt. Nationen 10.10.2007. www.nationen.no/meninger/kommentar/ article3048993.ece (7.2.2012).

9. Gjessing H, Pihlstrøm L. En trussel mot verdens helse. Dagens Medisin 16.12.2011. www.dagensmedisin.no/debatt/en-trussel-motverdens-helse/ (22.12.2011)

Mottatt 11.1.2012 og godkjent 2.2. 2012. Medisinsk redaktør Siri Lunde. 